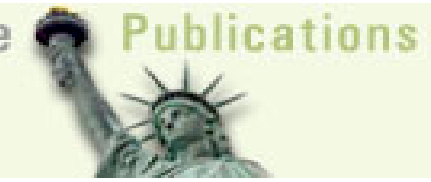

American Journal of Environmental Sciences 4 (1): 1-12, 2008

ISSN $1553-345 \mathrm{X}$

(C) 2008 Science Publications

\title{
Total $\mathrm{SO}_{2}$ Emissions from Power Stations and Evaluation of their Impact in Kuwait Using a Gaussian Plume Dispersion Model
}

\author{
A.A. Ramadan, M. Al-Sudairawi, S. Alhajraf and A.R. Khan \\ Coastal and Air Pollution Department, Kuwait Institute for Scientific Research \\ P.O. Box 24885, 13109 Safat - Kuwait
}

\begin{abstract}
In Kuwait, most of the power stations use fuel oil as the prime source of energy. The sulphur content ( $\mathrm{S} \%$ ) of the fuel used as well as other factors have a direct impact on the ground level concentration of sulphur dioxide $\left(\mathrm{SO}_{2}\right)$ released by power stations into the atmosphere. The $\mathrm{SO}_{2}$ ground level concentration has to meet the environmental standards set by Kuwait Environment Public Authority (KEPA). In this communication we present results obtained using the Industrial Sources Complex Short Term (ISCST3) model to calculate the $\mathrm{SO}_{2}$ concentration resulting from existing power stations in Kuwait assuming zero background $\mathrm{SO}_{2}$ concentration and entire reliance on Heavy Fuel Oil. $1,2,3$ and $4 \mathrm{~S} \%$ scenarios were simulated for three emission cycle cases. The computed annual $\mathrm{SO}_{2}$ concentrations were always less than KEPA standards for all scenarios. The daily $\mathrm{SO}_{2}$ concentrations were within KEPA standards for $1 \mathrm{~S} \%$ but violated KEPA standards for higher $\mathrm{S} \%$. In general, the concentrations obtained from the combined hourly and seasonal cycle were the lowest and those obtained from the no cycle case were the highest. The comparison between the results of the three cycles revealed that the violation times cannot be solely attributed to the increase in emissions and the meteorological conditions have to be taken into consideration.
\end{abstract}

Key words: Air pollution, ISCST3, sulphur dioxide

\section{INTRODUCTION}

In the last century, advancement in industrialisation and medical care has elevated the living standards and increased the population and their life expectancy. This development has resulted in great constrain on the environment in the form of increased atmospheric pollution, global climate change, etc. Amongst the major atmospheric pollutants is sulphur dioxide $\left(\mathrm{SO}_{2}\right)$. $\mathrm{SO}_{2}$ emissions from power stations account for $69 \%$ of total emissions, whilst $13 \%$ comes from burning fuel in manufacturing industries and construction. According to Hamzeh ${ }^{[1]}$, the World Bank estimates that the transport sectors' contribution to global $\mathrm{SO}_{2}$ emissions is between $2-6 \%$. With this in mind, the importance of capping the $\mathrm{SO}_{2}$ emissions from power stations is indisputable. In order to plan the required fuel quality for the existing and planned power stations, it is imperative to consider the variation of air pollutant concentrations due to different types of fuels as well as the behaviour of these pollutants in response to the prevailing meteorological conditions. The presented work examines the effect of the load cycles on the ground level concentration of $\mathrm{SO}_{2}$ as well as the effect of $\mathrm{S} \%$.
Boix $^{[2]}$ have used vectorial model to assess the influence of local breeze and other meteorological parameters on the ground level concentrations of $\mathrm{SO}_{2}$ and particulate matters in the urban area of CastellónSpain. They have reported a decrease in the concentrations of $\mathrm{SO}_{2}$ and particulate matters in winter months due to strong prevailing wind while measured concentrations in summer were higher than recorded in winter months. A decrease in concentrations was noticed in hot days in winter while no such phenomenon was observed in summer.

Honaganahalli and Seiber ${ }^{[3]}$ have compared Industrial Source Complex Short Term 3 (ISCST3 - a plume dispersion model) with CALPUFF (a puff dispersion model) for several fumigated fields serving as source for methyl bromide $\left(\mathrm{CH}_{3} \mathrm{Br}\right)$ in the Salinas Valley-California. The simulated results were compared with the field measurement from 11 sites on the adjacent mountains, valley floor and at Pacific Ocean coast over a 4 days period. For Seiber et al. ${ }^{[4]}$ flux values, ISCST3 model under-predicted concentrations for $76 \%$ of data (the predicted concentrations were $66 \%$ of those measured) while the CALPUFF model also under-predicted $67 \%$ of observations (the predicted

Corresponding Author: A.A. Ramadan, Coastal and Air Pollution Department, Kuwait Institute for Scientific Research, P.O. Box 24885, 13109 Safat - Kuwait 
concentrations were $84 \%$ of the measured). For Yates et $a l .^{[5]}$ flux values, ISCST3 model over-predicted concentrations by a factor of 2 for $67 \%$ of data and CALPUFF over-predicted concentrations by a factor of 1.6 for over $50 \%$ of data.

Other researchers, e.g. Barna and Gimson ${ }^{[6]}$, Levy et $a l .{ }^{[7]}$ and Zhou et $a l^{[8]}$ have evaluated the performance of CALPUFF for different pollutant sources including home heating, motor vehicles, power plants and general industries. Their results will not be discussed here due to space limitations.

The power stations in Kuwait: The existing five power stations in Kuwait (Fig. 1) are: 1) Doha East (DE), 2) Doha West (DW), 3) Subiya (SUB), 4) Zour South (ZS) and 5) Shuaiba South (SH). The chimneys' design in SUB, ZS, DW is identical as each station has two chimneys each of which contains four stacks. DE differs slightly as it has two chimneys, one of which has four stacks and the other has three stacks. Each station was represented by a number of point sources equal to the number of chimneys in the station. This was done based on the recommendation of The ${ }^{[9]}$ and is similar to presentation of sources by Al-Ajmi and Marmoush ${ }^{[10]}$, Al-Ajmi and Marmoush ${ }^{[11]}$, Al-Awadhi et al. ${ }^{[12]}$, Ramadan et al. ${ }^{[13]}$, Ramadan et al. ${ }^{[14]}$ and Ramadan et $a l .{ }^{[15]}$.

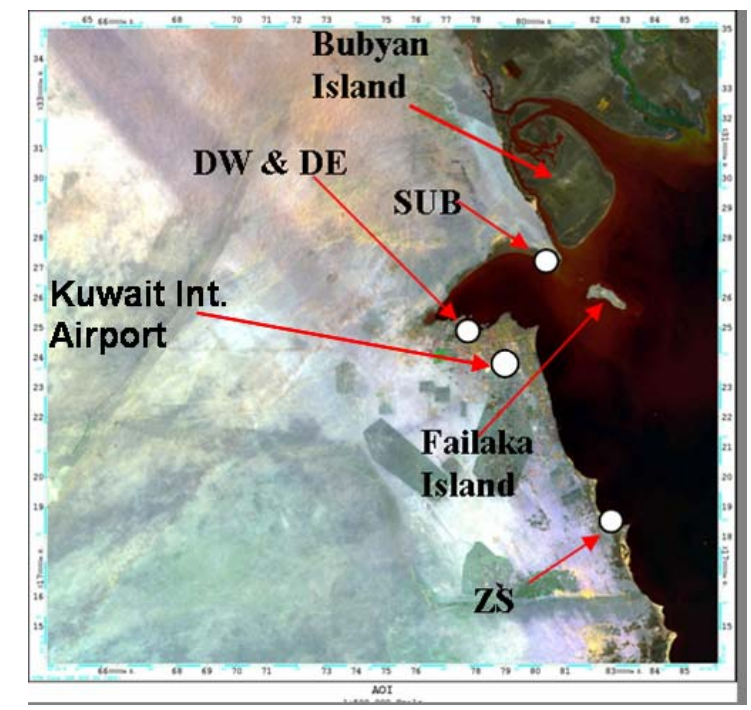

Fig. 1: Power stations in Kuwait

The diameter for the point source was the equivalent diameter to the three/four stacks in the chimney. The exit speed is considered the same but the emission rate is the sum of that for the four stacks. The stacks locations, elevations and diameters and the exit speeds and temperatures and the peak emission rates are listed in Table 1. The $\mathrm{SO}_{2}$ emission rate for each of the power stations was expressed as a function of the sulphur content (S\%) in the liquid fuel and the specified fuel consumption rate. The seasonal-hourly cycle of power generation was based on information provide by the National Control Centre-Ministry of Energy (NCCMOE).

The numerical model: The Industrial Source Complex - Short Term (ISCST3) dispersion model is an airquality model based on the Gaussian-plume simplification of the diffusion equation that assumes time independence in the input meteorology and source concentration. The ISCST3 algorithm calculates concentrations of non-reactive pollutants and/or deposition fluxes from a wide variety of sources. The ISCST3 dispersion model which was designed to support the US-EPA's regulatory modelling options does not take into account changes due to photoreactions. The model is capable of predicting results within $25 \mathrm{~km}$ radius from the point source, hence "Short Term".

The model was run using 1999-2003 meteorological data collected at Kuwait International Airport (Fig. 1) and it was assumed to be representative of the meteorological data of the entire State of Kuwait. (Fig. 2) shows the windrose plot for 1999-2003. The stability class was defined on the basis of Pasquill categories $^{[16]}$. The rural and urban mixing heights as well as the friction velocity, Monin-Obukhov length and roughness length at the application site were included in the meteorological data files used.

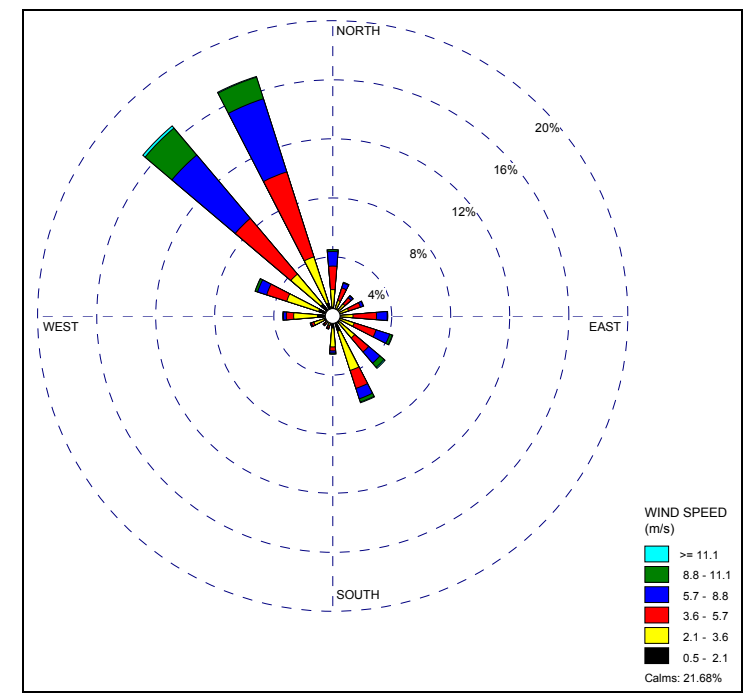

Fig. 2: Hourly wind data for Kuwait (1999-2003) 
Am. J. Environ. Sci., 4 (1): 1-12, 2008

Table 1: Stacks locations, elevations and diameters and the exit speeds and temperatures and the peak emission rates used in the model

\begin{tabular}{lllllllllll}
\hline $\begin{array}{l}\text { Power } \\
\text { Station }\end{array}$ & $\begin{array}{l}\text { No. of stacks } \\
\text { in Chimney }\end{array}$ & $\begin{array}{l}\mathrm{H} \\
(\mathrm{m})\end{array}$ & $\begin{array}{l}\mathrm{T} \\
(\mathrm{K})\end{array}$ & $\begin{array}{l}\mathrm{V} \\
\left(\mathrm{ms}^{-1}\right)\end{array}$ & $\begin{array}{l}\mathrm{D} \\
\mathrm{m}\end{array}$ & $\begin{array}{l}\text { Equivalent D Emission Rate } \\
\mathrm{m}\end{array}$ & $\begin{array}{l}\text { Equivalent } \\
\text { [er stack }\left(\mathrm{gs}^{-1}\right)\end{array}$ & $\begin{array}{l}\mathrm{X} \\
\text { Emission rate }\end{array}$ & $\mathrm{Y}$ \\
\hline DW1 & 4 & 190 & 408 & 23.719 & 4.238 & 8.656 & 409.379968 & 1637.519872 & 769685 & 3250890 \\
DW2 & 4 & 190 & 408 & 23.719 & 4.238 & 8.656 & 409.379968 & 1637.519872 & 769716 & 3250550 \\
DE1 & 4 & 190 & 408 & 18.934 & 3.488 & 6.976 & 219.268391 & 877.0735645 & 770608 & 3251030 \\
DE2 & 4 & 190 & 408 & 18.934 & 3.488 & 6.041 & 219.268391 & 657.8051733 & 770629 & 3250795 \\
SUB1 & 4 & 193 & 423 & 23.719 & 4.500 & 9.000 & 286.727860 & 1146.911444 & 802927 & 3274322 \\
SUB2 & 4 & 193 & 423 & 23.719 & 4.500 & 9.000 & 286.727860 & 1146.911444 & 802917 & 3274149 \\
SZ1 & 4 & 192 & 403 & 23.719 & 4.300 & 8.600 & 422.654922 & 1690.619692 & 828062 & 3180719 \\
SZ2 & 4 & 192 & 403 & 23.719 & 4.300 & 8.600 & 422.654922 & 1690.619692 & 827843 & 3180701 \\
\hline
\end{tabular}

Table 2: Ambient air quality standards for residential areas in Kuwait

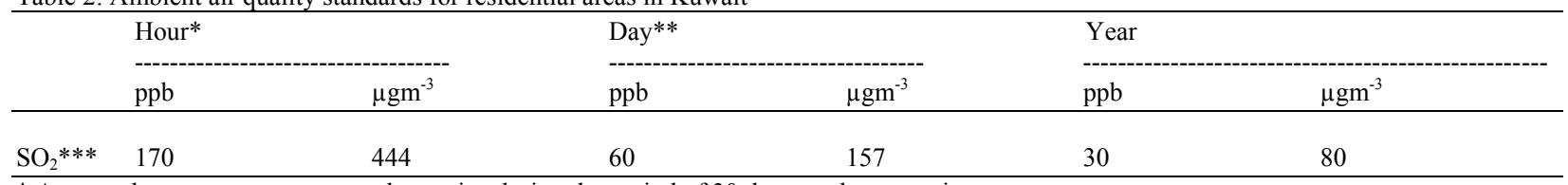

* Average hour not to occur more than twice during the period of 30 days on the same site

** Daily average (24 hours) should occur once during the year

*** Should apply in residential dominated areas that lie on the border of industrial areas

The model was executed using three uniform square grids each with 441 grid points as receptors. The centre of the three grids coincided with the centroid point for the station(s) considered.

The first uniform grid covered an area of $50 \mathrm{~km} \times 50 \mathrm{~km}$ with grid spacing of $2.5 \mathrm{~km}$. Second and third finer grids (areas of $20 \mathrm{~km} \times 20 \mathrm{~km}$ and $10 \mathrm{~km} \times 10 \mathrm{~km}$ with grid spacing of $1 \mathrm{~km}$ and $0.5 \mathrm{~km}$ respectively) were superimposed over the first coarse grid for accurate evaluation of the concentrations around the centroid of the power stations. A uniform terrain elevation grid of 382 by 332 grid points at $500 \mathrm{~m}$ spacing covering a total area of $190.5 \mathrm{~km}$ by $165.5 \mathrm{~km}$ was used in ISCST3 calculations. The main assumptions made can be summarised as:

* The background $\mathrm{SO}_{2}$ level (due to refineries, transportation, other industries, etc) is assumed zero.

* Due to the limitation of the ISCST model application, for calculations a $25 \mathrm{~km}$ radius domain from the point source at the centre, the model was executed for the following cases independently: 1) DW \& DE, 2) SUB and 3) ZS.

* SH uses natural gas for electric power generation which does not contain any sulphur compounds $\left(\mathrm{H}_{2} \mathrm{~S}\right.$ or mercaptans) and it was decided to exclude it from the present study.

* The remaining four power stations were assumed to rely entirely on Heavy Fuel Oil (HFO). This assumption though seems pragmatic, had to be made to simplify the modelling part of the project.
The annual total energy generated from each station was calculated, then the amount of HFO required to produce this amount of energy under existing operating conditions was found. S\% in the fuel was then varied to cover $1,2,3$ and $4 \mathrm{~S} \%$ (assuming no change in calorific value with $\mathrm{S} \%$ variation).

* No flue gas desulphurisation units were used in the stations.

* The effect of building downwash was not considered.

* No plume depletion, whether wet or dry, was used.

* The electrical energy was assumed to be generated from steam turbine units only.

To assess the effect of the load cycle on $\mathrm{SO}_{2}$ ground level concentration, the model was run for the following cases: 1) Peak load (No load cycle), 2) Seasonal cycle only and 3) Hourly and seasonal cycle. For each case, different scenarios $(1,2,3$ and $4 \mathrm{~S} \%)$ in fuel were tested.

Variations in emission rates: ISCST3 has several options to input the variable emission rates. For this study, the hour and season (96 values) option was chosen and the cycle was applied to all sources. The actual emission rate for each source was fed in the source constant emissions data and multiplicative scaling factors in the variable emissions data. The data obtained from NCC-MOE was used to calculate the scaling factors resulting in four curves for winter (December, January and February), spring (March, April and May), summer (June, July and August) and autumn (September, October and November) as illustrated in (Fig. 3). 


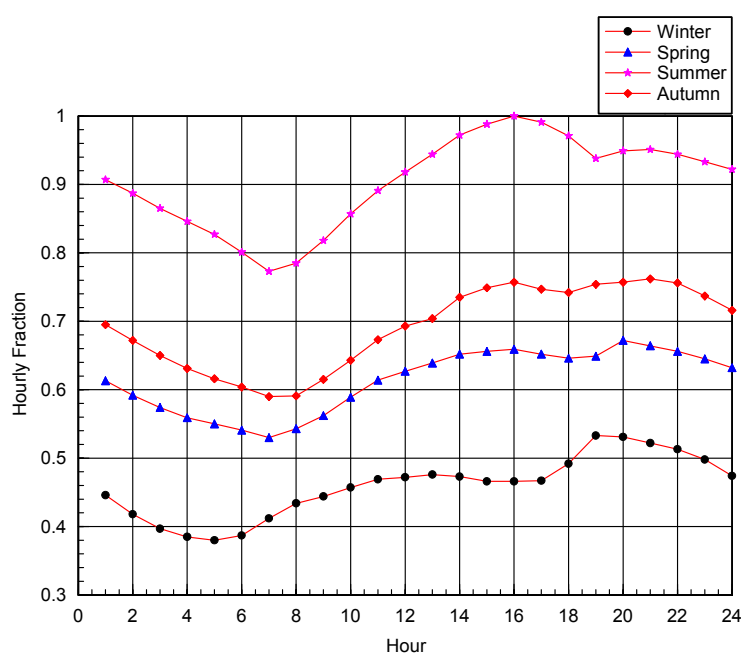

Fig. 3: Hourly fractions for different seasons as used in the numerical model

\section{RESULTS AND DISCUSSION}

The crucial emission rate used here corresponds to the maximum fuel consumption for the existing peak load at 16 hour during summer. This emission rate is assumed constant with time and is used for the entire year for a special case, i.e. Case $\mathrm{A}$, to investigate the influence of meteorological parameters. In Case B, the load was assumed independent of the hour of the day but it varied with season, hence the term "seasonal load cycle". The seasonal load cycle multiplicative factors were: winter season (51\%), spring season (68\%), summer season (100\%) and autumn season (77\%). For Case $\mathrm{C}$, the emission rates varied both hourly and seasonally following the hourly fractions curves shown in Fig. 3.

In this communication, due to space limitations, the hourly and annual $\mathrm{SO}_{2}$ concentrations will not be discussed in details and reference to it will only be made when necessary. The daily isopleths plots will present only the regions of $\mathrm{SO}_{2}$ concentrations above KEPA residential threshold values (Table 2).

Case A: Peak load (no cycle): It is interesting to note that the high hourly $\mathrm{SO}_{2}$ concentrations occur between 11-14 hours during May 2000, August 2000, August 2001 and June and August 2003. These high concentrations at these times are solely due to the weather conditions as the emission rates were kept constant throughout these runs. The computed yearly $\mathrm{SO}_{2}$ concentrations resulting from DE and DW, SUB and ZS were systematically below KEPA Annual

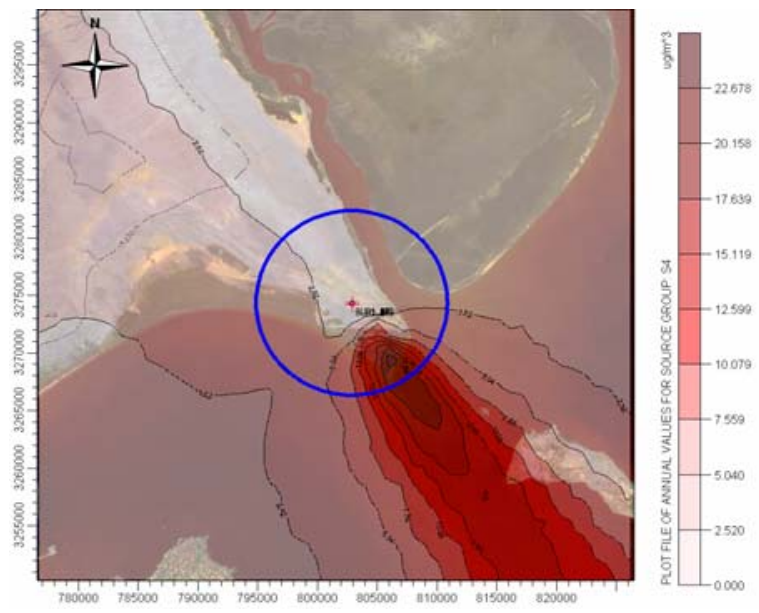

Fig. 4: Annual $\mathrm{SO}_{2}$ concentrations for $\mathrm{SUB}$ at $4 \mathrm{~S} \%$ with $r_{A}=$ $0 \%$ - CASE A

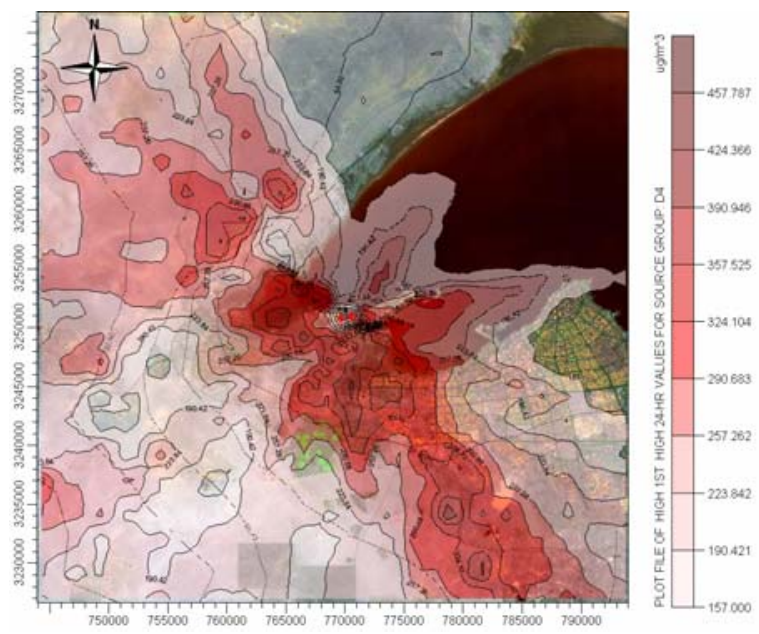

Fig. 5: Daily $\mathrm{SO}_{2}$ concentrations for DW DE at $4 \mathrm{~S} \%$ with $r_{A}=$ $75.83 \%$ - CASE A

Standard (KEPAAS) value of $80 \mu \mathrm{gm}^{-3}$ even for $4 \mathrm{~S} \%$, hence, no violation of KEPA annual standards. The effect of the prevailing north-western wind direction (Fig. 2) is indisputable in the annual concentrations isopleths and the plume is perfectly aligned with the wind direction, (Fig. 4.) The maximum annual concentrations are listed in Table 3.

Doha east and doha west power stations: The stacks of DE and DW power stations are about $900 \mathrm{~m}$ apart. The cumulative effect of the emissions released by the two stations is unambiguous in the daily and annual concentrations. The calculated daily $\mathrm{SO}_{2}$ concentrations comply with KEPA Daily Standard (KEPADS) value of $157 \mu \mathrm{gm}^{-3}$ for $1 \mathrm{~S} \%$ but not for 2,3 and $4 \mathrm{~S} \%$. 
Am. J. Environ. Sci., 4 (1): 1-12, 2008

Table 3: The violation times and maximum concentrations - No Cycle case Doha West-Doha East Power Station

\begin{tabular}{|c|c|c|c|c|}
\hline $\mathrm{S} \%$ & Max. Conc. $\left(\mu \mathrm{g} \mathrm{m}^{-3}\right)$ & KEPA Violation & $\mathrm{r}_{\mathrm{A}} \%$ & Violation Time \\
\hline \multicolumn{5}{|l|}{ Daily } \\
\hline 1.00 & 114 & $\mathrm{~N}$ & 0.00 & N/A \\
\hline 2.00 & 229 & $\mathrm{Y}$ & 7.38 & 29 March, 4 May, 10 July \& 9 Aug 03 / 16 May, 4 Jun \& 18 Jun 00 \\
\hline 3.00 & 343 & Y & 51.67 & 30 March, 4 May, 10 July \& 9 Aug 03 / 16 May, 4 Jun \& 18 Jun 00 \\
\hline 4.00 & 458 & $\mathrm{Y}$ & 75.83 & 31 March, 4 May, 10 July \& 9 Aug 03 / 16 May, 4 Jun \& 18 Jun 00 \\
\hline \multicolumn{5}{|r|}{ (6) } \\
\hline 1.00 & 16 & $\mathrm{~N}$ & 0.00 & N/A \\
\hline 2.00 & 33 & $\mathrm{~N}$ & 0.00 & N/A \\
\hline 3.00 & 49 & $\mathrm{~N}$ & 0.00 & N/A \\
\hline 4.00 & 66 & $\mathrm{~N}$ & 0.00 & N/A \\
\hline \multicolumn{5}{|c|}{ Subiya Power Station } \\
\hline $\mathrm{S} \%$ & $\operatorname{Max} \operatorname{Conc}\left(\mu \mathrm{g} \mathrm{m}^{-3}\right)$ & KEPA Violation & $\mathrm{r}_{\mathrm{A}} \%$ & Violation Time \\
\hline \multicolumn{5}{|l|}{ Daily } \\
\hline 1.00 & 67 & $\mathrm{~N}$ & 0.00 & N/A \\
\hline 2.00 & 133 & $\mathrm{~N}$ & 0.00 & N/A \\
\hline 3.00 & 200 & $\mathrm{~N}$ & 0.00 & N/A \\
\hline 4.00 & 267 & $\mathrm{Y}$ & 0.40 & $\begin{array}{l}3 \text { Jun \& 28Jul } 99 \text { / } 5 \text { Apr, } 16 \text { May \& } 18 \text { Jun 00/ } 2 \text { \& } 12 \text { Aug, } 18 \text { Sep 01/ } \\
29 \text { March, } 1 \text { Jul \& } 9 \text { Aug } 03\end{array}$ \\
\hline \multicolumn{5}{|r|}{ ( } \\
\hline 1.00 & 6 & $\mathrm{~N}$ & 0.00 & N/A \\
\hline 2.00 & 11 & $\mathrm{~N}$ & 0.00 & N/A \\
\hline 3.00 & 17 & $\mathrm{~N}$ & 0.00 & N/A \\
\hline 4.00 & 23 & $\mathrm{~N}$ & 0.00 & N/A \\
\hline \multicolumn{5}{|c|}{ Zour South Power Station } \\
\hline $\mathrm{S} \%$ & $\operatorname{Max}$ Conc $\left(\mu \mathrm{g} \mathrm{m}^{-3}\right)$ & KEPA Violation & $\mathrm{r}_{\mathrm{A}} \%$ & Violation Time \\
\hline \multicolumn{5}{|c|}{ (1) } \\
\hline 1.00 & 145 & $\mathrm{~N}$ & 0.00 & N/A \\
\hline 2.00 & 291 & $\mathrm{Y}$ & 0.14 & $4 \& 18$ Jun $00 / 9 \& 13$ Aug $03 / 9$ Jun 03 \\
\hline 3.00 & 436 & $\mathrm{Y}$ & 4.35 & 5 May, 4 \& 18 Jun \& 14 Sept $00 / 9 \& 13$ Aug $03 \& 9$ Jun 03 \\
\hline 4.00 & 581 & $\mathrm{Y}$ & 15.44 & 5 May, $4 \& 18$ Jun \& 14 Sep 00/ $9 \& 13$ Aug $03 \& 9$ Jun 03 \\
\hline \multicolumn{5}{|c|}{ Annual } \\
\hline 1.00 & 10 & $\mathrm{~N}$ & 0.00 & N/A \\
\hline 2.00 & 20 & $\mathrm{~N}$ & 0.00 & N/A \\
\hline 3.00 & 31 & $\mathrm{~N}$ & 0.00 & $\mathrm{~N} / \mathrm{A}$ \\
\hline 4.00 & 41 & $\mathrm{~N}$ & 0.00 & $\mathrm{~N} / \mathrm{A}$ \\
\hline
\end{tabular}

For 2,3 and $4 \mathrm{~S} \%$. The ratio of the area affected by the exceedences to the calculation-domain area $\left(r_{A}=\frac{A_{\text {Exceedence }}}{A_{\text {Calculation Domain }}} \times 100 \%\right)$ was $7.38,51.67$ and $75.83 \%$ respectively. The exceedences are listed in Table 3. The maximum daily concentration occurs at $4.1 \mathrm{~km}$ from the stations to the north-western direction (angle $=57.6^{\circ}$ ). The sign convention is the normal one, i.e. North $=0^{\circ}$ with $\mathrm{CCW}$ rotation. Figure 5 shows the daily concentration isopleths for $4 \mathrm{~S} \%$.

Subiya Power Station: There is no violation of KEPADS at $1 \& 2 \mathrm{~S} \%$. For $3 \mathrm{~S} \%$, the calculated daily $\mathrm{SO}_{2}$ concentration exceeded $157 \mu \mathrm{gm}^{-3}$ but only once a year, hence there is no violation of KEPADS for $3 \mathrm{~S} \%$. For $4 \mathrm{~S} \%$, KEPADS is violated not just only during summer but also during spring season, with the highest daily concentration attained being $267 \mu \mathrm{gm}^{-3}$. As Fig. 6

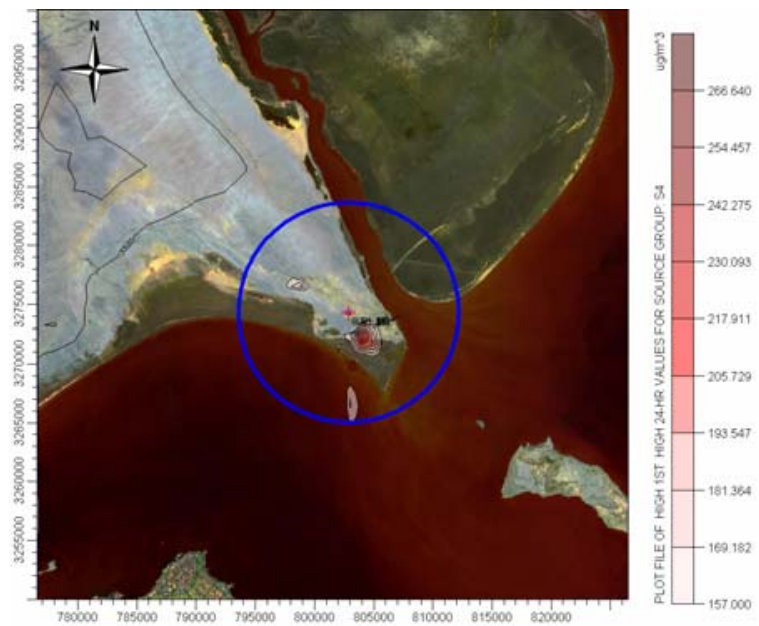

Fig. 6: Daily $\mathrm{SO}_{2}$ concentrations for $\mathrm{SUB}$ at $4 \mathrm{~S} \%$ with $r_{A}=$ $0.40 \%$ - CASE A 


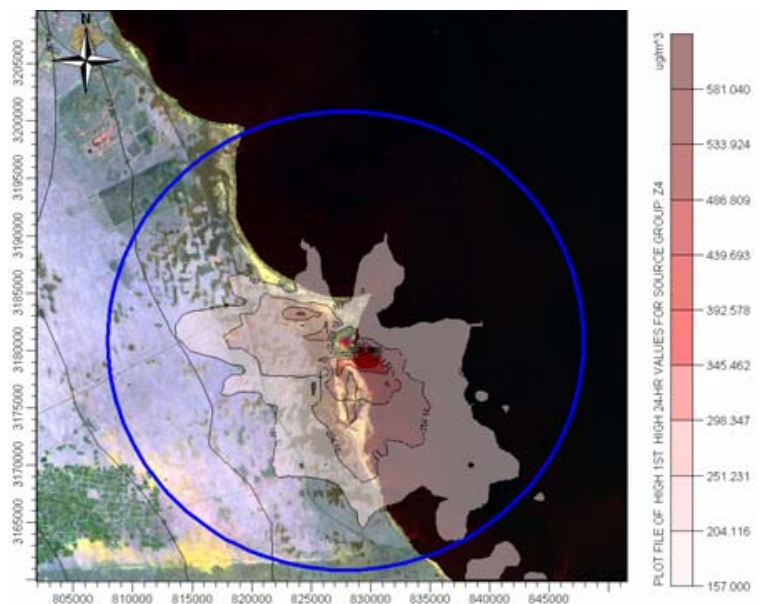

Fig. 7: Daily $\mathrm{SO}_{2}$ concentrations for $\mathrm{ZS}$ at $4 \mathrm{~S} \%$ with

$$
r_{A}=15.44 \%-\mathrm{CASE} \mathrm{A}
$$

shows, at $4 \mathrm{~S} \%$ the region affected by daily $\mathrm{SO}_{2}$ concentrations above KEPADS is very small, i.e. $r_{A}=$ $0.40 \%$ and it is enclosed within a circle of $9.3 \mathrm{~km}$ radius from the centroid of SUB. The point of highest concentration is at $1.75 \mathrm{~km}$ from the station and the effect of the prevailing north-western wind direction onsets to be apparent as this point is at $210^{\circ}$ from the station (southeast). The maximum daily concentrations with violation times are listed in Table 3 .

Zour South Power Station: For 1S\%, the computed daily concentrations show no violation of KEPADS. At $2 \mathrm{~S} \%$, KEPADS is violated and the maximum daily

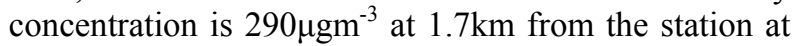
an angle of $225^{\circ}$ (southeast). At $4 \mathrm{~S} \%$, the region affected by daily $\mathrm{SO}_{2}$ concentrations higher than KEPADS can be enclosed by a circle of $20 \mathrm{~km}$ radius as can be seen in (Fig. 7) $r_{A}$ changes from $0.14 \%$ at $2 \mathrm{~S} \%$ to $15.44 \%$ at $4 \mathrm{~S} \%$.

Case B: Seasonal cycle: For this case, the high hourly $\mathrm{SO}_{2}$ concentrations continued to come about between 11-14 hours in the summers of 1999, 2000 and 2001. These high concentrations are not a result of increased emissions at these times as no hourly cycle was used in the calculations. Unfavourable meteorological conditions in the form of low wind speed and eastern wind direction are expected to be the reason behind these violations. This argument is supported by the findings of Alkama and Ourtirane ${ }^{[17]}$. The fact that the high hourly concentrations take place in some years but not the others strengthens the argument that the reason

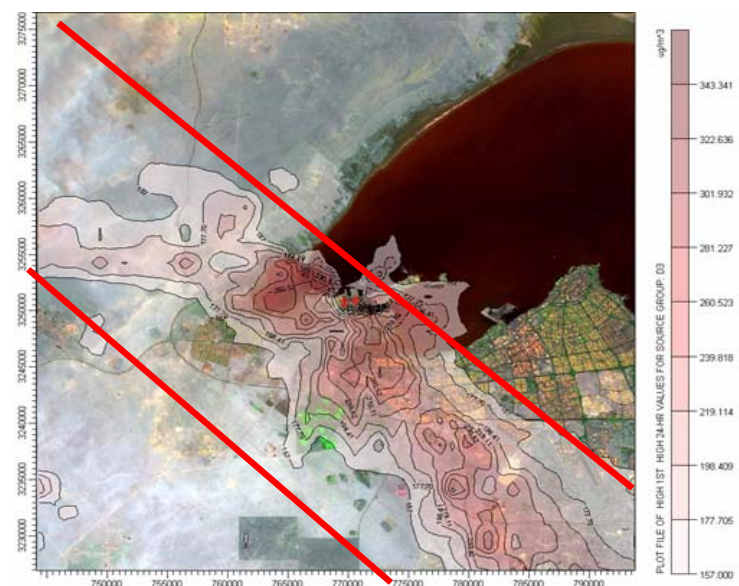

Fig. 8: Daily $\mathrm{SO}_{2}$ concentration due to DW \& DE at $3 \mathrm{~S} \%$ with $r_{A}=27.59 \%-\mathrm{CASE} \mathrm{B}$

behind these violations is related to the meteorological conditions rather than the variation in hourly load.

The computed yearly $\mathrm{SO}_{2}$ concentrations due to $\mathrm{DE}$ and DW, SUB and ZS are less than KEPAAS for the range of $\mathrm{S} \%$ under consideration and no violations of KEPAAS have been observed. The highest yearly average concentration for $4 \mathrm{~S} \%$ is approximately $21 \%$ less than the corresponding value for Case $\mathrm{A}$ and 8 to $12 \%$ higher than the corresponding value for Case $\mathrm{C}$. The maximum annual concentrations are listed in Table 4.

Doha East and Doha West power stations: For 1S\%, the computed maximum daily $\mathrm{SO}_{2}$ concentration is less than KEPADS. However, KEPADS is violated during summer at 2, 3 and $4 \mathrm{~S} \%$ due to the increased generation of electrical energy to cope with the higher demands during summer. Urban areas are affected by high daily $\mathrm{SO}_{2}$ concentrations even for $2 \mathrm{~S} \%$, for which $r_{A}=$ $4.40 \%$. For $3 \mathrm{~S} \%$, the region affected by high $\mathrm{SO}_{2}$ concentration grows, i.e. $r_{A}=27.59 \%$, to form a $5-10 \mathrm{~km}$ wide segment aligned with the prevailing wind direction in Kuwait, (Fig. 8). This region continually grows for $4 \mathrm{~S} \%$ affecting more urban areas and placing most of the high concentration points downwind of the stations (south-east). At $4 \mathrm{~S} \%, r_{A}=54.33 \%$ and the calculated maximum daily $\mathrm{SO}_{2}$ concentration was $458 \mu \mathrm{gm}^{-3}$, which is about 3 times the KEPADS and nearly $6 \%$ greater than the corresponding value for Case C.

Subiya power station: For $1-3 \mathrm{~S} \%$, there is no violation of KEPADS. At $4 \mathrm{~S} \%$, KEPADS is violated with a computed maximum daily concentration of $267 \mu \mathrm{gm}^{-3}$ 
Am. J. Environ. Sci., 4 (1): 1-12, 2008

Table 4: The violation times and maximum concentrations - Seasonal Cycle Doha West-Doha East Power Station

\begin{tabular}{|c|c|c|c|c|}
\hline $\mathrm{S} \%$ & Max Conc $\left(\mu \mathrm{g} \mathrm{m}^{-3}\right)$ & KEPA Violation & $r_{A} \%$ & Violation Time \\
\hline \multicolumn{5}{|l|}{$\overline{\text { Daily }}$} \\
\hline 1.00 & 114 & $\mathrm{~N}$ & 0.00 & N/A \\
\hline 2.00 & 229 & $\mathrm{Y}$ & 4.40 & $\begin{array}{l}\text { 12 Jun } 99 / 17 \text { Aug } 99 / 4 \& 18 \text { Jun } 00 / 12 \& 28 \text { Aug } 01 / 9 \\
\text { Jul } 02 / 30 \text { Aug } 02 / 10 \text { Jul } 03 / 9 \text { Aug } 03\end{array}$ \\
\hline 3.00 & 343 & $\mathrm{Y}$ & 27.59 & $\begin{array}{l}\text { 12 Jun } 99 / 17 \text { Aug } 99 / 4 \& 18 \text { Jun } 00 / 12 \& 28 \text { Aug } 01 / 9 \\
\text { Jul } 02 / 30 \text { Aug }\end{array}$ \\
\hline \multirow[t]{2}{*}{4.00} & 458 & $\mathrm{Y}$ & 54.33 & $\begin{array}{l}\text { 12 Jun } 99 / 17 \text { Aug } 99 / 4 \& 18 \text { Jun } 00 / 12 \& 28 \text { Aug } 01 / 9 \\
\text { Jul } 02 / 30 \text { Aug }\end{array}$ \\
\hline & \multicolumn{4}{|c|}{ Annual } \\
\hline 1.00 & 13 & $\mathrm{~N}$ & 0.00 & N/A \\
\hline 2.00 & 27 & $\mathrm{~N}$ & 0.00 & N/A \\
\hline 3.00 & 40 & $\mathrm{~N}$ & 0.00 & N/A \\
\hline 4.00 & 54 & $\mathrm{~N}$ & 0.00 & N/A \\
\hline \multicolumn{5}{|c|}{ Subiya Power Station } \\
\hline $\mathrm{S} \%$ & Max Conc $\left(\mu \mathrm{g} \mathrm{m}^{-3}\right)$ & KEPA Violation & $\mathrm{r}_{\mathrm{A}} \%$ & Violation Time \\
\hline \multicolumn{5}{|l|}{$\overline{\text { Daily }}$} \\
\hline 1.00 & 67 & $\mathrm{~N}$ & 0.00 & N/A \\
\hline 2.00 & 133 & $\mathrm{~N}$ & 0.00 & N/A \\
\hline 3.00 & 200 & $\mathrm{~N}$ & 0.00 & N/A \\
\hline 4.00 & 267 & $\mathrm{Y}$ & 0.27 & 3 Jun, $11 \& 28$ Jul 99/9 Aug \& 1 Jul 03 \\
\hline \multicolumn{5}{|c|}{ Annual } \\
\hline 1.00 & 5 & $\mathrm{~N}$ & 0.00 & N/A \\
\hline 2.00 & 9 & $\mathrm{~N}$ & 0.00 & N/A \\
\hline 3.00 & 14 & $\mathrm{~N}$ & 0.00 & N/A \\
\hline 4.00 & 19 & $\mathrm{~N}$ & 0.00 & N/A \\
\hline \multicolumn{5}{|c|}{ Zour South Power Station } \\
\hline $\mathrm{S} \%$ & Max Conc $\left(\mu \mathrm{g} \mathrm{m}^{-3}\right)$ & KEPA Violation & $\mathrm{r}_{\mathrm{A}} \%$ & Violation Time \\
\hline \multicolumn{5}{|l|}{ Daily } \\
\hline 1.00 & 145 & $\mathrm{~N}$ & 0.00 & $\mathrm{~N} / \mathrm{A}$ \\
\hline 2.00 & 291 & $\mathrm{Y}$ & 3.33 & $4 \& 18$ Jun $00 / 9 \& 13$ Aug $03 / 9$ Jun 03 \\
\hline 3.00 & 436 & $\mathrm{Y}$ & 0.00 & $4 \& 18$ Jun $00 / 9 \& 13$ Aug $03 / 9$ Jun 03 \\
\hline 4.00 & 581 & $\mathrm{Y}$ & 10.44 & $4 \& 18$ Jun $00 / 9 \& 13$ Aug $03 / 9$ Jun 03 \\
\hline \multicolumn{5}{|c|}{ Annual } \\
\hline 1.00 & 8 & $\mathrm{~N}$ & 0.00 & N/A \\
\hline 2.00 & 17 & $\mathrm{~N}$ & 0.00 & N/A \\
\hline 3.00 & 25 & $\mathrm{~N}$ & 0.00 & N/A \\
\hline 4.00 & 34 & $\mathrm{~N}$ & 0.00 & N/A \\
\hline
\end{tabular}

(9\% greater than the corresponding value for Case C) at $1.75 \mathrm{~km}$ from the station to the south-east and $r_{A}=0.27 \%$. The locations for the 50 highest daily concentrations are within a circle of $8.8 \mathrm{~km}$ radius around SUB. The maximum daily concentrations are listed in Table 4.

Zour South power station: KEPADS is violated at 2, 3 and $4 \mathrm{~S} \%$. The violation takes place during the summers (due to increased fuel consumption to meet the higher demand on electricity) of 2000 and 2003 further supporting the argument used for the cases of SUB, DW and DE stations. For $2 \mathrm{~S} \%, r_{A}=0.12 \%$ and it grows to reach $r_{A}=3.33 \%$ for $3 \mathrm{~S} \%$. The highest daily $\mathrm{SO}_{2}$ concentration obtained for $4 \mathrm{~S} \%$ was $581 \mu \mathrm{gm}^{-3}$ and
$r_{A}=10.44 \%$. Fig. 9 shows that the region suffering from daily $\mathrm{SO}_{2}$ concentrations above KEPADS for $4 \mathrm{~S} \%$ can be enclosed by a circle of $20 \mathrm{~km}$ radius.

Case C: Variable load: For this case, the highest hourly $\mathrm{SO}_{2}$ concentrations continue to transpire between 11-14 hours during the summer season. On the outlook, the time of violations can be linked to the shape of the hourly load curve shown in (Fig. 3), i.e. the power generation load after 11 hours is always more than $90 \%$ with its peak at 16 hours for the summer season. However, this argument is weakened by the fact that these high concentrations do not occur in all years (which have the same load cycle as the other years when high concentrations occur) leaving the meteorological conditions to play the major role is the 

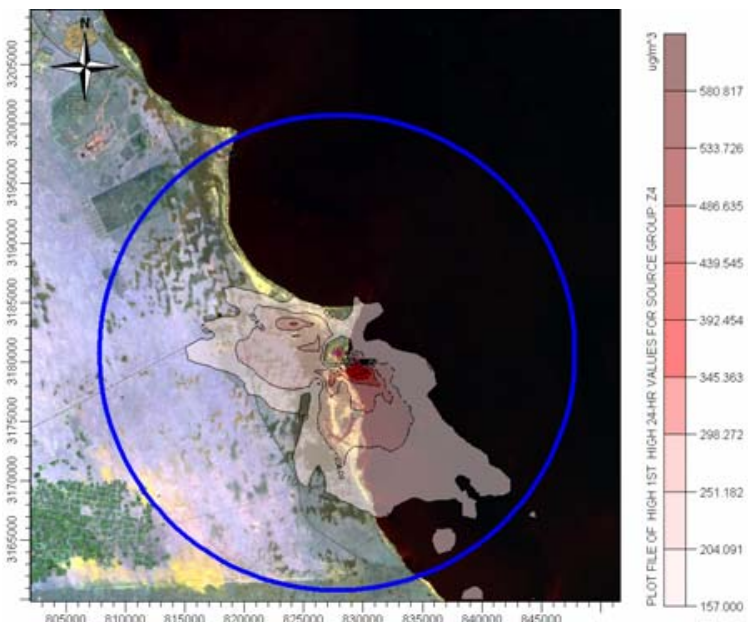

Fig. 9: Daily $\mathrm{SO}_{2}$ concentration due to $\mathrm{ZS}$ at $4 \mathrm{~S} \%$ with $r_{A}=10.44 \%-$ CASE B

computed ground level concentrations.

The yearly $\mathrm{SO}_{2}$ concentrations resulting from $\mathrm{DE}$ and DW, SUB and ZS are less than KEPAAS for all $\mathrm{S} \%$ considered, hence, no violations of KEPAAS are noticed. The plume remains aligned with the prevailing wind direction and all the high concentration points are to the south east of the stations, highlighting the advantage of the locations of SUB and ZS. The maximum annual concentrations are listed in Table 5.

Doha East and Doha West power stations: The computed daily $\mathrm{SO}_{2}$ concentrations resulting from $1 \mathrm{~S} \%$ are less than KEPADS. For 2, 3 and $4 \mathrm{~S} \%$, the KEPADS is violated every summer season when the coefficients of the power generation seasonal/hourly cycle is the highest and the appropriate meteorological conditions are met. At $2 \mathrm{~S} \%$, the region affected by high daily $\mathrm{SO}_{2}$ concentrations is relatively small, $r_{A}=2.14 \%$ and no urban area is affected. As can be (Fig. 10), the regions affected by $\mathrm{SO}_{2}$ concentration violating the KEPADS increase outreaching urban areas for 3 and $4 \mathrm{~S} \%$ for which $r_{A}=21.63 \%$ and $45.40 \%$ respectively. The highest daily $\mathrm{SO}_{2}$ concentration obtained for $4 \mathrm{~S} \%$ was $432 \mathrm{ggm}^{-3}$ (nearly 3 times the KEPADS) at $4.1 \mathrm{~km}$ distance and angle $=58^{\circ}$ (north west of the stations).

Subiya Power Station: The daily $\mathrm{SO}_{2}$ concentrations for $1-2 \mathrm{~S} \%$ are less than KEPADS. For $3 \mathrm{~S} \%$, the KEPADS is transcended at three locations, but only once a year (during June), hence no violation of KEPA standards for $3 \mathrm{~S} \%$ is observed. For $4 \mathrm{~S} \%$, KEPADS is violated with the highest daily concentration attained

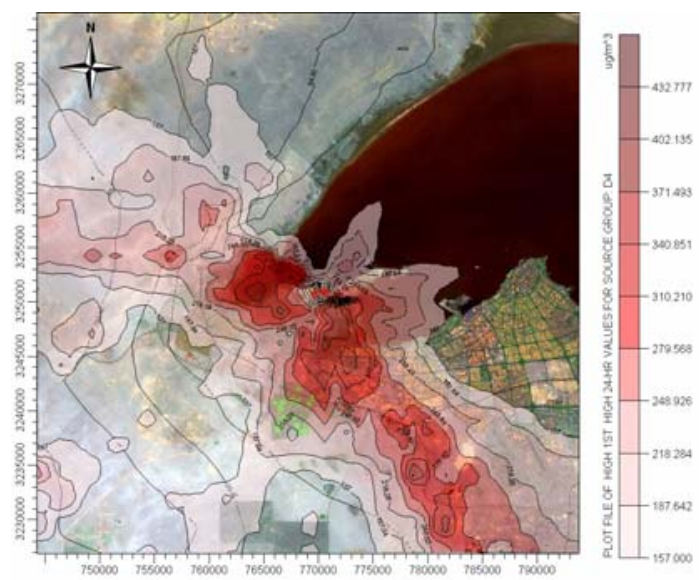

Fig. 10: Annual $\mathrm{SO}_{2}$ concentration due to $\mathrm{DW} \mathrm{DE}$ at $4 \mathrm{~S} \%$ with $r_{A}=45.40 \%$ - CASE C

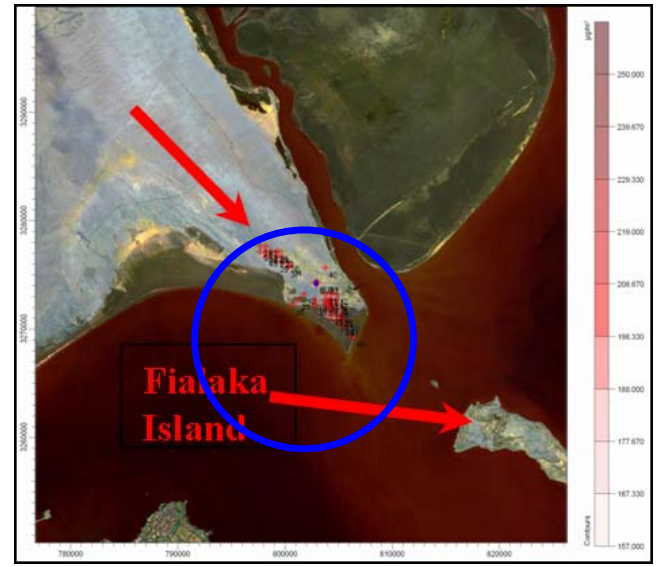

Fig. 11:Daily $\mathrm{SO}_{2}$ concentration due to SUB at $4 \mathrm{~S} \%$ with $r_{A}=0.19 \%$ - CASE C

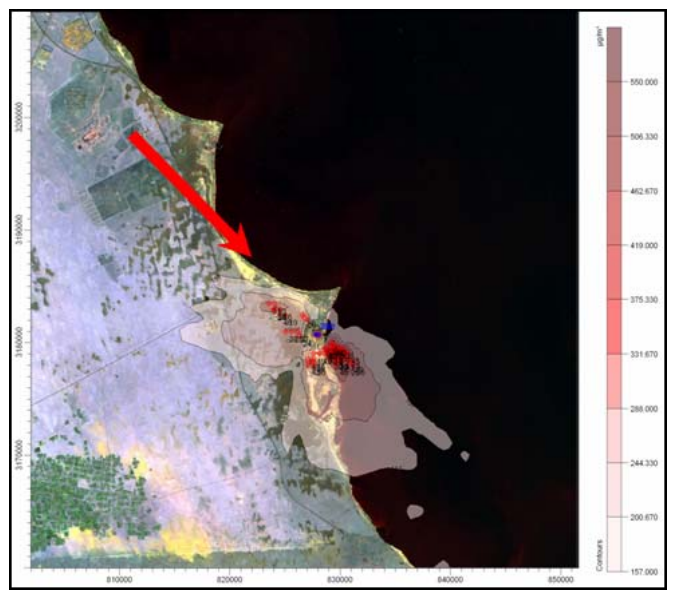

Fig. 12: Daily $\mathrm{SO}_{2}$ concentration due to $\mathrm{ZS}$ at $4 \mathrm{~S} \%$ with $r_{A}=8.18 \%-$ CASE C 
Am. J. Environ. Sci., 4 (1): 1-12, 2008

Table 5: The violation times and maximum concentrations - Hourly and Seasonal Cycle Doha West-Doha East Power Station

\begin{tabular}{|c|c|c|c|c|}
\hline $\mathrm{S} \%$ & Max Conc $\left(\mu \mathrm{g} \mathrm{m}^{-3}\right)$ & KEPA Violation & $r_{A} \%$ & Violation Time \\
\hline \multicolumn{5}{|l|}{$\overline{\text { Daily }}$} \\
\hline 1.00 & 108 & $\mathrm{~N}$ & 0.00 & N/A \\
\hline 2.00 & 216 & $\mathrm{Y}$ & 2.14 & $\begin{array}{l}12 \text { Jun } 99 / 17 \text { Aug } 99 / 4 \& 18 \text { Jun } 00 / 12 \& 28 \text { Aug } 01 / 9 \\
\text { Jul } 02 / 30 \text { Aug } 02 / 10 \text { Jul } 03 / 9 \& 20 \text { Aug } 03\end{array}$ \\
\hline 3.00 & 325 & $\mathrm{Y}$ & 21.63 & $\begin{array}{l}12 \text { Jun } 99 / 17 \text { Aug } 99 / 4 \& 18 \text { Jun } 00 / 12 \& 28 \text { Aug } 01 / 9 \\
\text { Jul } 02 / 30 \text { Aug } 02 / 10 \text { Jul } 03 / 9 \& 20 \text { Aug } 03\end{array}$ \\
\hline 4.00 & 433 & $\mathrm{Y}$ & 45.40 & $\begin{array}{l}12 \text { Jun } 99 / 17 \text { Aug } 99 / 4 \& 18 \text { Jun } 00 / 12 \& 28 \text { Aug } 01 / 9 \\
\text { Jul } 02 / 30 \text { Aug } 02 / 10 \text { Jul } 03 / 9 \& 20 \text { Aug } 03\end{array}$ \\
\hline \multicolumn{5}{|c|}{ Annual } \\
\hline 1.00 & 12 & $\mathrm{~N}$ & 0.00 & N/A \\
\hline 2.00 & 25 & $\mathrm{~N}$ & 0.00 & N/A \\
\hline 3.00 & 37 & $\mathrm{~N}$ & 0.00 & N/A \\
\hline 4.00 & 50 & $\mathrm{~N}$ & 0.00 & N/A \\
\hline \multicolumn{5}{|c|}{ Subiya Power Station } \\
\hline $\mathrm{S} \%$ & Max Conc $\left(\mu \mathrm{g} \mathrm{m}^{-3}\right)$ & KEPA Violation & $\mathrm{r}_{\mathrm{A}} \%$ & Violation Time \\
\hline \multicolumn{5}{|l|}{$\overline{\text { Daily }}$} \\
\hline 1.00 & 62 & $\mathrm{~N}$ & 0.00 & N/A \\
\hline 2.00 & 123 & $\mathrm{Y}$ & 0.00 & N/A \\
\hline 3.00 & 185 & $\mathrm{Y}$ & 0.00 & N/A \\
\hline 4.00 & 246 & $\mathrm{Y}$ & 0.19 & 3 Jun \& 28 Jul 99 / 9 Aug \& 1 Jul 03 \\
\hline \multicolumn{5}{|c|}{ Annual } \\
\hline 1.00 & 4 & $\mathrm{~N}$ & 0.00 & N/A \\
\hline 2.00 & 9 & $\mathrm{~N}$ & 0.00 & N/A \\
\hline 3.00 & 13 & $\mathrm{~N}$ & 0.00 & N/A \\
\hline 4.00 & 17 & $\mathrm{~N}$ & 0.00 & N/A \\
\hline \multicolumn{5}{|c|}{ Zour South Power Station } \\
\hline $\mathrm{S} \%$ & $\operatorname{Max} \operatorname{Conc}\left(\mu \mathrm{g} \mathrm{m}^{-3}\right)$ & KEPA Violation & $\mathrm{r}_{\mathrm{A}} \%$ & Violation Time \\
\hline \multicolumn{5}{|l|}{ Daily } \\
\hline 1.00 & 135 & $\mathrm{~N}$ & 0.00 & N/A \\
\hline 2.00 & 270 & $\mathrm{Y}$ & 0.09 & $4 \& 18$ Jun $00 / 9 \& 13$ Aug / 9 Jun 03 \\
\hline 3.00 & 404 & $\mathrm{Y}$ & 2.52 & $4 \& 18$ Jun $00 / 9 \& 13$ Aug / 9 Jun 03 \\
\hline 4.00 & 539 & $\mathrm{Y}$ & 8.18 & $4 \& 18$ Jun $00 / 9 \& 13$ Aug / 9 Jun 03 \\
\hline \multicolumn{5}{|r|}{ - } \\
\hline 1.00 & 7 & $\mathrm{~N}$ & 0.00 & N/A \\
\hline 2.00 & 15 & $\mathrm{~N}$ & 0.00 & N/A \\
\hline 3.00 & 23 & $\mathrm{~N}$ & 0.00 & N/A \\
\hline 4.00 & 31 & $\mathrm{~N}$ & 0.00 & N/A \\
\hline
\end{tabular}

being $246 \mu \mathrm{gm}^{-3}$ at $1.75 \mathrm{~km}$ from the station to the southeastern direction. The region affected by high daily $\mathrm{SO}_{2}$ concentrations is unnoticeable, i.e. $r_{A}=0.19 \%$ and it can be enclosed by a circle of $6.24 \mathrm{~km}$ radius, (Fig. 11). The north-western and south-eastern winds force the locations of high concentrations to scatter around a straight line stretching from northwest to southeast.

For ZS, the KEPADS is violated for 2, 3 and $4 \mathrm{~S} \%$ cases. Similar to SUB, DW and DE stations, the highest daily $\mathrm{SO}_{2}$ concentrations transpire during summer. The highest daily $\mathrm{SO}_{2}$ concentration obtained for $4 \mathrm{~S} \%$ was $539 \mu \mathrm{gm}^{-3}$. At $2 \mathrm{~S} \%$, the region affected by high daily $\mathrm{SO}_{2}$ concentrations is small, i.e. $r_{A}=0.09 \%$ and no urban area is affected. The regions influenced by $\mathrm{SO}_{2}$ concentration above KEPADS grow in both northwestern and south-eastern directions for 3 and $4 \mathrm{~S} \%$ as can be (Fig. 12). The 50 highest concentrations take place within a circle of $4.75 \mathrm{~km}$ radius.

\section{CONCLUSION}

The maximum computed hourly and daily ground level concentrations are the same for the no cycle and seasonal cycle cases and they occur during the summer season. For these two cases, the emission rate is consistent for the entire year for the no cycle case and is equivalent to the emission rate for the summer period for the seasonal cycle case resulting in identical maximum ground level concentration at a specific location and time for the prevailing meteorological conditions. For hourly and seasonal combined cycle there is $9.2 \%$ and $7.3 \%$ average reduction in computed values of hourly and daily ground level concentrations 
respectively (compared to the no cycle and seasonal cycle cases) due to continuous hourly variation in emission rates throughout the year. The annual computed ground level concentrations are different for all three cycles depicting the annual variation in emission rates from no cycle to seasonal and combined hourly and seasonal cycle. There has been $21.1 \%$ reduction due to season seasonal cycle and $31.4 \%$ reduction for the most realistic operation conditions for combined hourly and seasonal cycle.

The ratio of the area affected by the exceedences to the calculation-domain area, i.e. $r_{A}$, is affected by two factors: $\mathrm{S} \%$ and the emission cycle as illustrated in Figs. 13 and 14. $r_{A}$ increases with $\mathrm{S} \%$ until $r_{A}$ reaches $100 \%$ when further increase in $\mathrm{S} \%$ results in increased ground level concentrations only. $r_{A}$ increases gradually as we move from the combined hourly and seasonal cycle to the seasonal cycle and finally to the no cycle case.

Other findings are:

* KEPADS is maintained if all the power stations use $\mathrm{HFO}$ with $1 \mathrm{~S} \%$ or less.

* KEPAAS is maintained at all $\mathrm{S} \%$ simulated.

* All KEPA violations occur between 11-14 hours during summer season when the demand on electrical energy is high and the appropriate meteorological conditions are met.

* The effect of the north-western prevailing wind direction onsets to appear on daily results and is most profound on annual results.

* The concentrations obtained for the combined hourly and seasonal cycle were in general less than those of the constant and the seasonal cycle cases.

* The location of SUB station is ideal for extension or even building new power stations as even for $4 \mathrm{~S} \%$ under variable load conditions, the high hourly $\mathrm{SO}_{2}$ concentrations do not affect urban areas. This continues to be valid as long as Failaka Island remains uninhibited.

For the daily and annual $\mathrm{SO}_{2}$ concentrations, enhanced dispersion has the following effects: a) increasing the region of influence of high $\mathrm{SO}_{2}$ concentrations whilst causing the 50 higher $\mathrm{SO}_{2}$ concentrations to be reached closer to the source, $b$ ) increasing the maximum daily and annual $\mathrm{SO}_{2}$ concentrations.

The locations of the existing power stations have many benefits, e.g. a) proximity to sea water which is used for desalination as well as for steam turbines and cooling purposes and b) due to the prevailing north- western wind direction the high pollutant

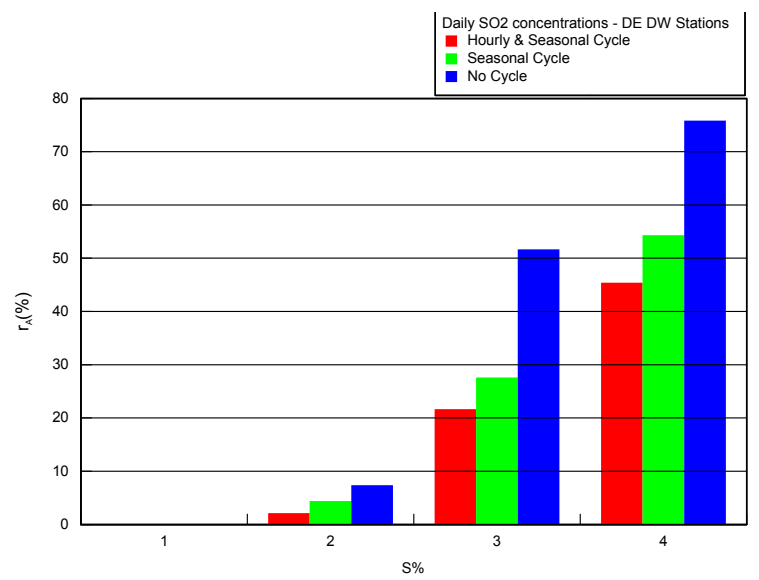

Fig. 13: Variation in the daily $r_{A}$ due to the change in $\mathrm{S} \%$ and the emission Cycle for DE DW stations

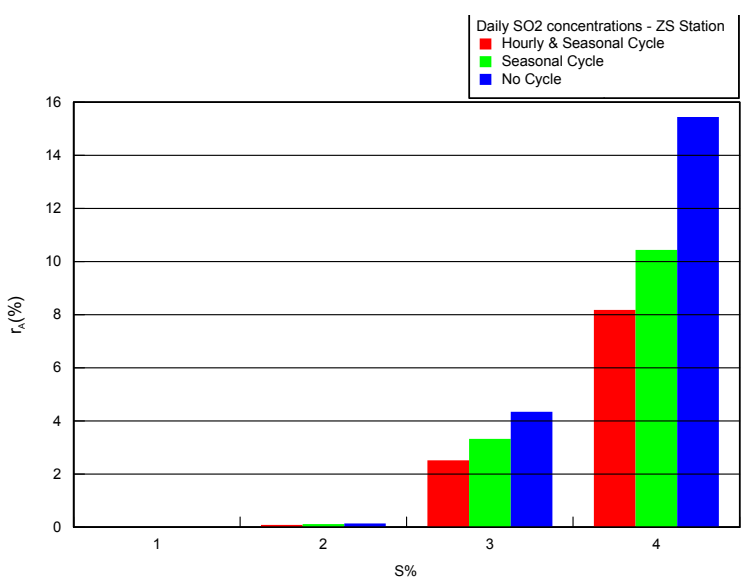

Fig. 14: Variation in the daily $r_{A}$ due to the change in $\mathrm{S} \%$ and the emission Cycle for ZS station

concentrations for ZS and SUB power stations occur offshore. However, the increased airborne pollutant levels above the Arabian Gulf is expected to have adverse effect on the marine life. Until the time has come to completely switch to cleaner fuels and renewable sources of energy the best solutions seems to improve the efficiency of power generation systems through: a) Combined-cycle systems, b) Combined heat and power production, c) System rehabilitation and boiler tuning and d) Electric power system interconnections (Hamzeh ${ }^{[1]}$ ).

When using the combined hourly and seasonal cycle in the calculations, i.e. Case $\mathrm{C}$, the violations of KEPA standards at 11-14 hours during the summer can be readily attributed to the higher demand on electricity at those times. This is plausible as the majority of employed people reach their houses after work at this 
Am. J. Environ. Sci., 4 (1): 1-12, 2008

time and the use of electrical utilities peaks. Hence, researchers tend to believe this surge in electricity usage is the main reason for the KEPA violations. However, when the model is run at constant load (Case A) and at seasonal load cycle with no hourly variation (Case B), the above mentioned argument is weakened. As the presented results have shown, the violations during 11-14 hours in some summer seasons continue directing attention to the meteorological conditions and their significant influence on dispersion of emissions. The argument is reinforced when one remembers that the violations took place during the above-mentioned times in the summers of 1999, 2000 and 2001 but not during 2002 and 2003 although the emissions were identical for all years. This is conceivable when considering that serious pollution episodes in cities aren't directly caused by sudden increase in pollutant emissions but result from unfavourable meteorological conditions, Alkama and Ourtirane ${ }^{[17]}$. According to them, the meteorological parameters that provoke pollutants increase are: temperature, relative humidity and wind.

The Careful examination of the meteorological data for times of violations reveals that the stability category for the violations times ranges between moderately unstable (stability category A) to extremely unstable (stability category B) category which is characterised by strong thermal instability and bright sun light.

At present we are trying to correlate the hourly, daily and annual results to meteorological data and this is expected to be the subject of future communication.

\section{ACKNOWLEDGEMENTS}

This research was supported by Kuwait National Petroleum Company. The authors gratefully acknowledge this support and the encouragement of Mr. A. Al-Jemaz and Mr. B. Al-Shumaimri.

\section{REFERENCES}

1. Hamzeh, A., 2004. Improving Air Quality by Reducing Emissions from Electric Power Industry. Case Study: Thermal Power Plants in Syria. Proceedings, Dubai International Conference on Atmospheric Pollution. Organised by Zayed International Prize for the Environment/Dubai International Convention Centre.

2. Boix, A., V. Compañ, M. M. Jordán and T. Sanfeliu, 1995. Vectorial model to study the local breeze regimen and its relationship with $\mathrm{SO}_{2}$ and particulate matter concentrations in the urban area of Castellón, Spain. Science of Total Environment, 172: 1-15.
3. Honaganahalli, P.S. and J.N. Seiber, 2000. Measured and predicted airshed concentrations of methyl bromide in an agricultural valley and applications to exposure assessment. Atmospheric Environment, 34: 3511-3523.

4. Seiber, J.N., J.E. Woodrow, P.S. Honaganahalli, J.S. LeNoir and K.C. Dowling, 1996. Dispersion characteristics and sink for airborne methyl bromide downwind of a treated agriculture field. In Seiber, J. N., J. A. Knuteson, J. E. Woodrow, N. L. Wolf, M. V. Yates, S. R. Yates, (Eds.) Fumigants: Environment Fate, Exposure and Analysis ACS Symposium Series 652. American Chemical Society, Washington, DC, pp: 154-177.

5. Yates, R.S., J. Gan, F.F. Ernst, D. Wang and V.M. Yates, 1996. Emissions of methyl bromide from agriculture fields: rate estimates and method of reduction. In Seiber, J. N., J. A. Knuteson, J. E. Woodrow, N. L. Wolf, M. V. Yates, S. R. Yates, (Eds.) Fumigants: Environment Fate, Exposure and Analysis ACS Symposium Series 652. American Chemical Society, Washington, DC, pp: 116-134.

6. Barna, M.G. and N.R. Gimson, 2002. Dispersion modelling of a wintertime particulate pollution episode in Christchurch, New Zealand. Atmospheric Environment 36:3531-3544.

7. Levy, J.I., J.D. Spengler, D. Hlinka, D. Sullivan and D. Moon, 2002. Using CALPUFF to evaluate the impacts of power plant emissions in Illinois: model sensitivity and implications. Atmospheric Environment 36: 1063-1075.

8. Zhou, Y., J.I. Levy, J.K. Hammitt and J.S. Evans, 2003. Estimating population exposure to power plant emissions using CALPUFF: a case study in Beijing, China. Atmospheric Environment 37: 815826.

9. The, J. L., 2005. Personal communication. President of Lakes Environmental Software Inc. Ontario, Canada.

10 Al-Ajmi, D. and Y. Marmoush, 1996. Ground-level concentration of sulphur dioxide at Kuwait's major population centers during the oil-field fires. Environ. Inter., 22: 279-287.

11. Al-Ajmi, D. and Y. Marmoush, 1992. Estimating the air quality impact of Kuwait oil field fires during July-September 1991. Kuwait Institute for Scientific Research, Report No. KISR 4132, Kuwait.

12. Al-Awadhi, J., M. Al-Sudairawi and Y. Marmoush, 2000. The ground-level concentration of the pollutant sulphur dioxide released by the power stations until the year 2010. Kuwait Institute for Scientific Research, Report No. KISR 5803, Kuwait. 
13. Ramadan, A. A., M. Al-Sudairawi, S. Al-Hajraf and A. Khan, 2005. Prediction of the allowed sulphur content in the fuel used by the power stations in Kuwait. IASME Transactions, 8: 15781589.

14. Ramadan, A. A., M. Al-Sudairawi and S. AlHajraf, 2006a. Prediction of $\mathrm{SO}_{2}$ ground level concentration due to the power stations in Kuwait seasonal cycle case. World Renewable Energy Congress IX, Aug. 2006, Italy. Organised by World Renewable Energy Congress/Network (WREC/WREN), PO Box 362, Brighton, BN2 1YH, UK.

15. Ramadan, A.A., M. Al-Sudairawi and S. Al-Hajraf, 2006b. Prediction of SO2 ground level concentration due to the power stations in Kuwait variable load case. World Renewable Energy Congress IX, Aug. 2006, Italy. Organised by World Renewable Energy Congress/Network (WREC/WREN), P.O. Box 362, Brighton, BN2 $1 \mathrm{YH}, \mathrm{UK}$.
16. Turner, D.B., 1970. Workbook of atmospheric dispersion estimates. US Environmental Protection Agency, Office of Air Program. Publication No. AP-26, Research Triangle Park, North Carolina, US.

17. Alkama, R. and K. Ourtirane, 2004. Statistical study of air pollution from mobile source emissions in the Bejaia city (Algeria). Proceedings, Dubai International Conference on Atmospheric Pollution. Organised by Zayed International Prize for the Environment/Dubai International Convention Centre. 